\title{
Identification and susceptibility of clinical isolates of Candida spp. to killer toxins
}

\author{
E. Robledo-Leal ${ }^{a}$, L. G. Rivera-Morales ${ }^{*}$, M. P. Sangorrín ${ }^{b}$, G. M. González ${ }^{c}$, \\ G. Ramos-Alfano ${ }^{a}$, J. M. Adame-Rodriguez ${ }^{a}, J$. M. Alcocer-Gonzalez ${ }^{a}$, \\ E. T. Arechiga-Carvajal and C. Rodriguez-Padilla ${ }^{a}$
}

\begin{abstract}
${ }^{a}$ Departamento de Microbiología e Inmunología, Facultad de Ciencias Biológicas, Universidad Autónoma de Nuevo León - UANL, Av. Universidad, s/n, Ciudad Universitaria, CP 66455, San Nicolás de los Garza, Nuevo León, México

${ }^{\mathrm{b}}$ Grupo de Biodiversidad y Biotecnología de Levaduras, Consejo Nacional de Investigaciones Científicas y Tecnológicas, Facultad de Ingeniería, Instituto de Investigación y Desarrollo en Ingeniería de Procesos, Biotecnología y Energías Alternativas - PROBIEN, Universidad Nacional del Comahue, Buenos Aires, 1400, CP 8300, Neuquén, Argentina

'Departamento de Microbiología, Facultad de Medicina, Universidad Autónoma de Nuevo León - UANL, Av. Francisco I. Madero Pte, s/n y Av. Gonzalitos, Monterrey, CP 64460, Nuevo León, México *e-mail: lydiariver@gmail.com
\end{abstract}

Received: February 9, 2017 - Accepted: May 11, 2017 - Distributed: November 30, 2018 (With 2 figures)

\begin{abstract}
Although invasive infections and mortality caused by Candida species are increasing among compromised patients, resistance to common antifungal agents is also an increasing problem. We analyzed 60 yeasts isolated from patients with invasive candidiasis using a PCR/RFLP strategy based on the internal transcribed spacer (ITS2) region to identify different Candida pathogenic species. PCR analysis was performed from genomic DNA with a primer pair of the ITS2-5.8S rDNA region. PCR-positive samples were characterized by RFLP. Restriction resulted in 23 isolates identified as C. albicans using AlwI, 24 isolates as C. parapsilosis using RsaI, and 13 as C. tropicalis using XmaI. Then, a group of all isolates were evaluated for their susceptibility to a panel of previously described killer yeasts, resulting in $75 \%$ being susceptible to at least one killer yeast while the remaining were not inhibited by any strain. C. albicans was the most susceptible group while $C$. tropicalis had the fewest inhibitions. No species-specific pattern of inhibition was obtained with this panel of killer yeasts. Metschnikowia pulcherrima, Pichia kluyveri and Wickerhamomyces anomalus were the strains that inhibited the most isolates of Candida spp.
\end{abstract}

Keywords: Candida, killer yeasts, yeast antagonism.

\section{Identificação e susceptibilidade de isolados clínicos de Candida spp. para toxinas assassinas}

\begin{abstract}
Resumo
Embora as infecções invasivas e a mortalidade causada por espécies de Candida estejam aumentando entre pacientes comprometidos, a resistência a agentes antifúngicos comuns também é um problema crescente. Analisamos 60 leveduras isoladas de pacientes com candidíase invasiva utilizando como estratégia PCR/RFLP baseada na região espaçadora transcrita interna (ITS2) para identificar diferentes espécies patogênicas de Candida. A análise por PCR foi realizada a partir de ADN genómico com um par de iniciadores da região ITS2-5.8S rDNA. As amostras PCR-positivas foram caracterizadas por RFLP. A restrição resultou em 23 isolados identificados como C. albicans usando AlwI, 24 isolados como $C$. parapsilosis usando RsaI e 13 como C. tropicalis usando XmaI. Em seguida, avaliou-se o grupo de todos os isolados quanto à sua susceptibilidade a um painel de leveduras killer previamente descritas, resultando em $75 \%$ sendo suscetíveis a pelo menos uma levedura killer, enquanto que as restantes não foram inibidas por qualquer cepa. C. albicans foi o grupo mais suscetível enquanto $C$. tropicalis teve o menor número de inibições. Não se obteve um padrão de inibição específico da espécie com este painel de leveduras killer. Metschnikowia pulcherrima, Pichia kluyveri e Wickerhamomyces anomalus foram as cepas que inibiram a maioria dos isolados de Candida spp.
\end{abstract}

Palavras-chave: Candida, levedura killer, antagonismo de leveduras. 


\section{Introduction}

Invasive infections caused by primary and opportunistic fungal pathogens have increased in immunocompromised patients for over two decades (Beck-Sagué and Jarvis, 1993). Most of these life-threatening infections are caused by different Candida species, which represent the most commonly yeasts isolated from bloodstream infections in patients in intensive care units and are the second cause of mortality in such patients (Wisplinghoff et al., 2004). In Mexico, the most frequent species is C. albicans $(70 \%)$, but the proportion of infections caused by Non-albicans Candida species (30\%) has been increasing (Hernández-Hernández et al., 2003).

Mortality associated to Candida infections ranges from $40 \%$ to $60 \%$ (Nucci et al., 1997). Furthermore, in the last decade, the emergence of infections caused by Candida species resistant to common antifungal agents has been increasing, such as those caused by C. krusei and $C$. glabrata resistant to fluconazole. Therefore, proper identification at species level is essential to provide appropriate therapy and reduce mortality in patients with invasive candidiasis. Furthermore, efforts are being made in order to develop new antifungal therapies that could overcome such resistances with a potential candidate being killer toxins secreted from other yeasts.

The killer phenomenon was described by Bevan and Makower (1963) and consists of the secretion of proteinaceous compounds (killer toxins) from yeasts that inhibit the growth of other yeasts. These killer toxins exhibit variations in their inhibition spectrum, mechanism of action, molecular size, optimum $\mathrm{pH}$ and temperature, and they have been described in more than 20 genera of yeast from both the ascomycetes and basidiomycetes phyla (Golubev, 1998), from either clinical or natural sources (Souza Cabral et al., 2009; Arroyo-Helguera et al., 2012). Reports from Magliani et al. (2004) and Polonelli et al. (2003) have shown that killer toxins pose an interesting strategy for the development of new antifungal treatments that could overcome antifungal resistance due to the evolutionary origin of these interactions.

In this study, we used a PCR/RFLP strategy based on the ITS2 region to identify at species level 60 clinical Candida isolates and then subjected them to a panel of previously isolated killer yeasts of diverse origin in order to evaluate their potential therapeutic application and look for patterns that may differentiate among species, as a potentially fast and low-cost identification technique.

\section{Material and Methods}

\subsection{Killer yeasts}

A panel of 19 previously isolated killer yeasts was selected, isolated and identified by Dr. Marcela Sangorrín (Table 1). The killer yeasts were identified by ITS1-5.8S-ITS2 rDNA PCR-RFLP analysis as described by Esteve-Zarzoso et al. (1999). Patterns obtained for each isolate after digestion with the restriction enzymes Cfo I, Hae III and Hinf 1
Table 1. Killer yeasts evaluated for their inhibitory activity of clinical isolates of Candida spp.

\begin{tabular}{cc}
\hline Strain No. & ID \\
\hline 1250 & Pichia membranifaciens \\
1127 & Metschnikowia pulcherrima \\
1144 & Metschnikowia pulcherrima \\
1123 & Metschnikowia pulcherrima \\
1023 & Metschnikowia pulcherrima \\
1025 & Wickerhamomyces anomalus \\
1027 & Wickerhamomyces anomalus \\
1015 & Wickerhamomyces anomalus \\
1018 & Wickerhamomyces anomalus \\
1026 & Wickerhamomyces anomalus \\
1033 & Torulaspora delbruecki \\
1036 & Torulaspora delbruecki \\
1147 & Pichia kluyveri \\
1150 & Pichia kluyveri \\
1151 & Pichia kluyveri \\
1153 & Pichia kluyveri \\
1148 & Pichia kluyveri \\
1263 & Cryptococcus victoriae \\
1268 & Cryptococcus weringae \\
\hline
\end{tabular}

were compared with those of reference strains available in the yeast identification database (Esteve-Zarzoso et al., 1999). Yeast identity was confirmed by sequencing the D1/D2 domains of the 26S rRNA gene (Kurtzman and Robnett, 1998). The sequences obtained for yeast isolates were compared with those published at GenBank database (available at the National Center for Biotechnology Information, NCBI) using BLAST.

\subsection{Clinical isolates}

A total of 60 clinical isolates were obtained from the mycology laboratory of the Centro Regional para el Control de Enfermedades Infecciosas at the Universidad Autónoma de Nuevo León. All Candida strains were grown on YPD broth ( $1 \%$ yeast extract, $2 \%$ casein peptone and $2 \%$ dextrose) for 24 hours at $37^{\circ} \mathrm{C}$ with shaking ( $230 \mathrm{rpm}$ ). Yeast identification was previously performed using the API 20 C AUX test (bioMérieux Vitek, Hazelwood, MO, USA) according to manufacturer's instructions.

\subsection{DNA isolation}

Yeast DNA was obtained by the technique described by Sambrook and Russell (2001). For cell wall disruption and subsequent extraction of DNA, we used the method described by Jin et al. (2004), with modifications. In brief, cells of each fungal culture were homogenized in $500 \mu \mathrm{L}$ of lyticase lysis buffer (50 mMtris, $\mathrm{pH} 7.6 ; 1$ mM EDTA, $0.2 \% 2$-mercaptoethanol, $10 \mu \mathrm{L}$ of lyticase $5 \mathrm{U} / \mu \mathrm{L})$ and incubated for 10 minutes at $37^{\circ} \mathrm{C}$. Cell wall disruption was performed by mixing with glass beads in a vortex. Extraction of DNA was carried out by precipitation with phenol-chloroform and 70\% ethanol. Finally, DNA was resuspended in $20 \mu \mathrm{L}$ of TE buffer (10 mMTris- $\mathrm{HCl}$, 
pH 8.0 and $0.1 \mathrm{mM}$ EDTA), $2 \mu$ Lof RNase $(10 \mathrm{mg} / \mathrm{mL})$ and stored at $-20^{\circ} \mathrm{C}$ until used.

\subsection{PCR amplification}

Primers ITS3 (5'-GCA TCG ATG AAG AAC GCA GC-3') and ITS4 (5'-TCC TCC GCT TAT TGA TAT GC-3') previously reported were used to amplify the ITS2-5.8S rDNA from the isolates (White et al., 2003). Amplification was performed using 5-10 ng of fungal DNA as template in a $50 \mu \mathrm{L}$ mix containing $100 \mathrm{ng}$ of each primer, $10 \mu \mathrm{M}$ of deoxyribonucleotide triphosphate mixture, $2.5 \mathrm{mM}$ of magnesium chloride, $5 \mu \mathrm{L}$ of 10X PCR buffer $(200 \mathrm{mM}$ Tris, $\mathrm{pH}$ 8.4; and $500 \mathrm{mM} \mathrm{KCl}$ ) and $2.5 \mathrm{U}$ of TaqDNA polymerase (Invitrogen, Carlsbad, CA, USA). A reaction mix without a template was used as a negative control. Amplification consisted of an initial denaturation step of 5 minutes at $94^{\circ} \mathrm{C}$, followed by 35 cycles. Each cycle consisted of a denaturation step at $95^{\circ} \mathrm{C}$ for 1 minute, annealing at $55^{\circ} \mathrm{C}$ for 1 minute and elongation at $72^{\circ} \mathrm{C}$ for 1.5 minutes, with a final elongation step at $72^{\circ} \mathrm{C}$ for 5 minutes, in a PTC-100 thermocycler (MJ Research, Waltham, MA, USA). All PCR products were separated by electrophoresis in 3.5\% agarose electrophoresis gels stained with ethidium bromide and visualized with the software LabImage 1D version 3.4.0 (Kapelan Bio-Imaging, Leipzig, Germany). Afterwards, samples were stored at $-20^{\circ} \mathrm{C}$ until used.

\subsection{Selection of restriction enzymes}

The nucleotide sequences of the ITS2-5.8S rDNA of various Candida species were analyzed first in silico using the NEBcutter software (New England BioLabs, Ipswich, MA, USA) to determine the different restriction patterns generated by the endonucleases. We selected RsaI, AlwI, $X m a \mathrm{I}, X h o \mathrm{I}$, and AatII due to the differential restriction patterns generated by them (Table 2).

\subsection{Restriction fragment length polymorphisms}

PCR-amplified ITS2-5.8S rDNA fragments from clinical isolates were digested with selected endonucleases in the appropriate buffer provided by the manufacturer (New England Biolabs, Ipswich, MA, USA). Digestion was carried out for 12 hours at $37^{\circ} \mathrm{C}$, in a total volume of $20 \mu \mathrm{L}$ containing $10 \mu \mathrm{L}$ of the PCR product, $5 \mathrm{U}$ of each restriction enzyme and the respective buffer solution. Digested materials were separated by electrophoresis in
$8.0 \%$ polyacrylamide gel stained with ethidium bromide and the restriction fragments were analyzed using the LabImage 1D version 3.4.0 (Kapelan Bio-Imaging, Leipzig, Germany).

\subsection{Killer assays}

The screening of killer activity was performed as reported previously (Robledo-Leal et al., 2012), using YEPD-MB agar (0.3\% Yeast extract, $0.3 \%$ Malt extract, $0.5 \%$ Peptone, $2 \%$ Glucose, $2 \%$ Agar and $0.003 \%$ Methylene blue, adjusted to $\mathrm{pH} 4.5$ with $0.1 \mathrm{M}$ citrate-phosphate buffer). Twenty-four-hour-old cultures of the clinical isolates were mixed with the YEPD-MB agar to obtain a final concentration of $1 \times 10^{6}$ cells per $\mathrm{mL}$. After homogenization, media was poured onto Petri plates. Killer strains were streaked as thick smears over the sensitive lawn and replicates were made for incubation at $25^{\circ} \mathrm{C}$ for up to $72 \mathrm{~h}$. The appearance of an inhibition zone surrounding the killer yeast bordered with a halo of dark-blue-stained cells was considered a positive indication of the presence of killer activity (Figure 1). Once the results were obtained, each assay was repeated for confirmation and reproducibility.

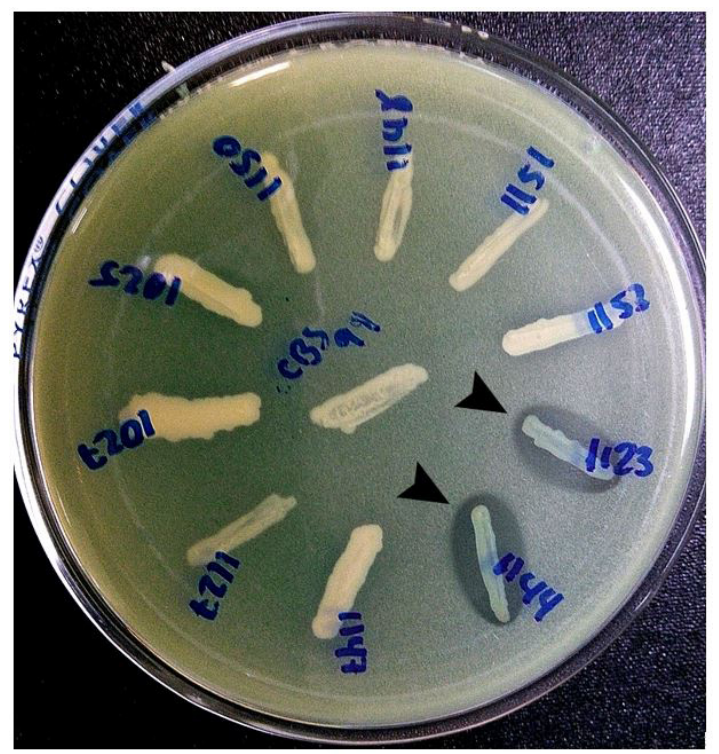

Figure 1. Sample of a killer assay. Strains 1123 and 1144 in the plate (arrowheads) exhibit the killer phenotype.

Table 2. Differential restriction patterns employed in this study.

\begin{tabular}{cccccc}
\hline Species & $\begin{array}{c}\text { GenBank } \\
\text { accession } \\
\text { number }\end{array}$ & $\begin{array}{c}\text { ITS2, } \\
\text { 5.8S and 28S } \\
\text { partial sequence } \\
\text { of rDNA (nt) }\end{array}$ & $\begin{array}{c}\text { Restriction } \\
\text { enzyme }\end{array}$ & $\begin{array}{c}\text { Restriction } \\
\text { fragments } \\
\text { length (nt) }\end{array}$ & $\begin{array}{c}\text { No. of clinical } \\
\text { isolates } \\
\text { identified }\end{array}$ \\
\hline C. rugosa & EU663569 & 271 & RsaI & 234,37 & 0 \\
C. albicans & EU663565 & 335 & AlwI & 208,127 & 23 \\
C. tropicalis & EU796734 & 327 & XmaI & 186,141 & 13 \\
C. lusitaniae & EU663568 & 255 & XhoI & $159,84,12$ & 0 \\
C. guilliermondii & EU663566 & 378 & RsaI & 210,168 & 0 \\
C. parapsilosis & ATCC 22019 & 311 & RsaI & 228,83 & 24 \\
\hline
\end{tabular}

ITS: Internal Transcribed Spacer; nt: nucleotides. 


\section{Results}

Amplification of the ITS2-5.8S rDNA region of the different reference Candida species generated PCR products ranging 271 to 378 base pairs (bp) in size (Figure 2). Enzymes that gave differential restriction fragment lengths in silico were employed in vitro to evaluate their differentiation of this strategy; electrophoresis in $8.0 \%$ polyacrylamide gel showed that the target bands corresponded to those predicted in silico.

To evaluate the reliability of the PCR/RFLP strategy used to identify clinical isolates of Candida, we extracted genomic DNA from 60 Candida isolates obtained from invasive infection cases. At least $100 \mathrm{ng}$ of DNA were used for the ITS2-5.8S rDNA amplification. Restriction resulted in 23 isolates identified as C. albicans using AlwI, 24 isolates as C. parapsilosis using RsaI, and 13 as C. tropicalis using XmaI.

\subsection{Susceptibility to killer yeasts}

All of the isolates were assayed against killer yeasts as described above (Table 3). Forty-five isolates (75\%) were sensitive against at least one killer yeast and the 15 remaining isolates were not inhibited by any killer strain. Candida albicans was the most susceptible group, with 142 combinations resulting in inhibition, compared to 53 in C. parapsilosis and 27 in C. tropicalis. With the exception of CP21, $C$. parapsilosis had the narrowest range of susceptibility, with only 6 different strains being able to inhibit them, while for C. albicans and C. tropicalis as many as 12 different killer yeasts were able to inhibit them. Killer strains 1123,1127 and 1144 were the most active, inhibiting the growth of 24 clinical isolates, including every one of C. albicans. None of the other killer yeasts was able to

A

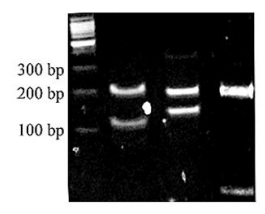

B

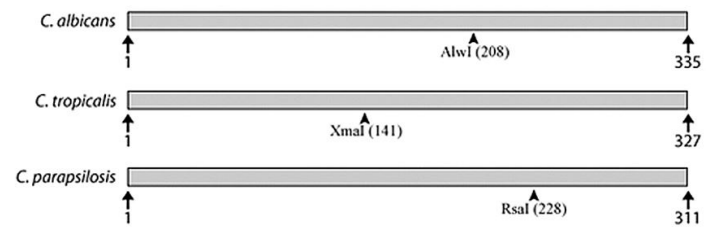

Figure 2. PCR/RFLP of the ITS2-5.8S region of the rRNA gene from different Candida species. (A) PCR-amplified fragments of the mentioned region plus restriction enzyme used. Lanes: 1: C. albicans + AlwI (208 and $127 \mathrm{bp})$; 2: C. tropicalis + XmaI (186 and $141 \mathrm{bp}) ; 3:$ C. lusitaniae + XhoI (84, 96 and 159 bp); 4: C. guilliermondii + RsaI (210 and $168 \mathrm{bp}$ ); 5: C. parapsilosis + RsaI (228 and $83 \mathrm{bp);}$ 6: C. rugosa + RsaI (37 and 234 bp). (B) Predicted (in silico) length and restriction map of the PCR-amplified fragments of the ITS2-5.8S region from different Candida species. inhibit a whole species group. The most susceptible strains were also within the $C$. albicans group, being inhibited by 12 different killer strains. No species-specific pattern of inhibition was obtained with this panel of killer yeasts.

\section{Discussion}

The incidence of pathogenic fungal species has a critical impact on clinical outcome in patients with invasive fungal infections, especially in immunocompromised patients. Although most of the clinically relevant fungal infections are caused by Candida species, it is important to identify the specific etiological agent to make an adequate choice of the antifungal therapy (Messer et al., 2009; Bourgeois et al., 2010). In order to provide a more rapid and reliable method for the identification of fungal species in invasive candidiasis, a number of molecular techniques have been developed. Several methods for specific fungal species identification are based on ITS2 ribosomal region variability, which is flanked by conserved sequences of rDNA (Fujita et al., 2001; Ferrer et al., 2001; Trost et al., 2004). The identification of fungal species using the ITS2 region has been described previously by Landlinger et al. (2009). They established a strategy based on PCR-fragment length analysis of the ITS2 region to identify fungal species from clinical specimens. The PCR/RFLP technique differentiated seven clinically important species of Candida. A limitation of a single ITS2-5.8S rDNA PCR fragment length analysis is the low variation of the fragment sizes between certain species, such as $C$. albicans and C. tropicalis, but they exhibit variation in their nucleotide sequences that are exploitable for differentiation using restriction enzymes. The site $A l w \mathrm{I}$ was conserved in 23 clinical isolates that had been previously identified by microbiological techniques as $C$. albicans, and the site $X m a I$ was present in 13 isolates identified as $C$. tropicalis. Killer activity depends on various factors being temperature and $\mathrm{pH}$ some of the most relevant, but the nature of the sensitive yeast may be the most important. Our experiments exhibit the strain-related property of the killer phenomenon as described by Golubev (1998). While some killer toxins have a broad spectrum of activity, in theory there is no such thing as a "universal" killer yeast, for it depends on receptors and thus phylogenic relatedness. Yeasts may be resistant to certain killer toxins due to the lack of receptors, or immune due to either mutations or cross-protection resulting from the secretion of a similar toxin. Metschnikowia pulcherrima strains 1023, 1123 and 1144 showed a complete inhibition of the C. albicans group; while this species' antimicrobial effect has been related to the production of pulcherrimic acid which is converted to the iron sequestering compound pulcherremin, instead of a proteinaceous agent, differences in the inhibition spectrum suggest the possibility of a killing factor different from or additional to this. On the other hand, strains 1153 (P. kluyveri) and 1025 (W. anomalus) exhibited a broad spectrum of inhibition as well (16 and 15 inhibitions respectively); both species have been reported before as producers of killer toxins and while these strains were 
Table 3. Interactions between killer yeasts and clinical isolates (only killer yeasts with positive reactions are shown).

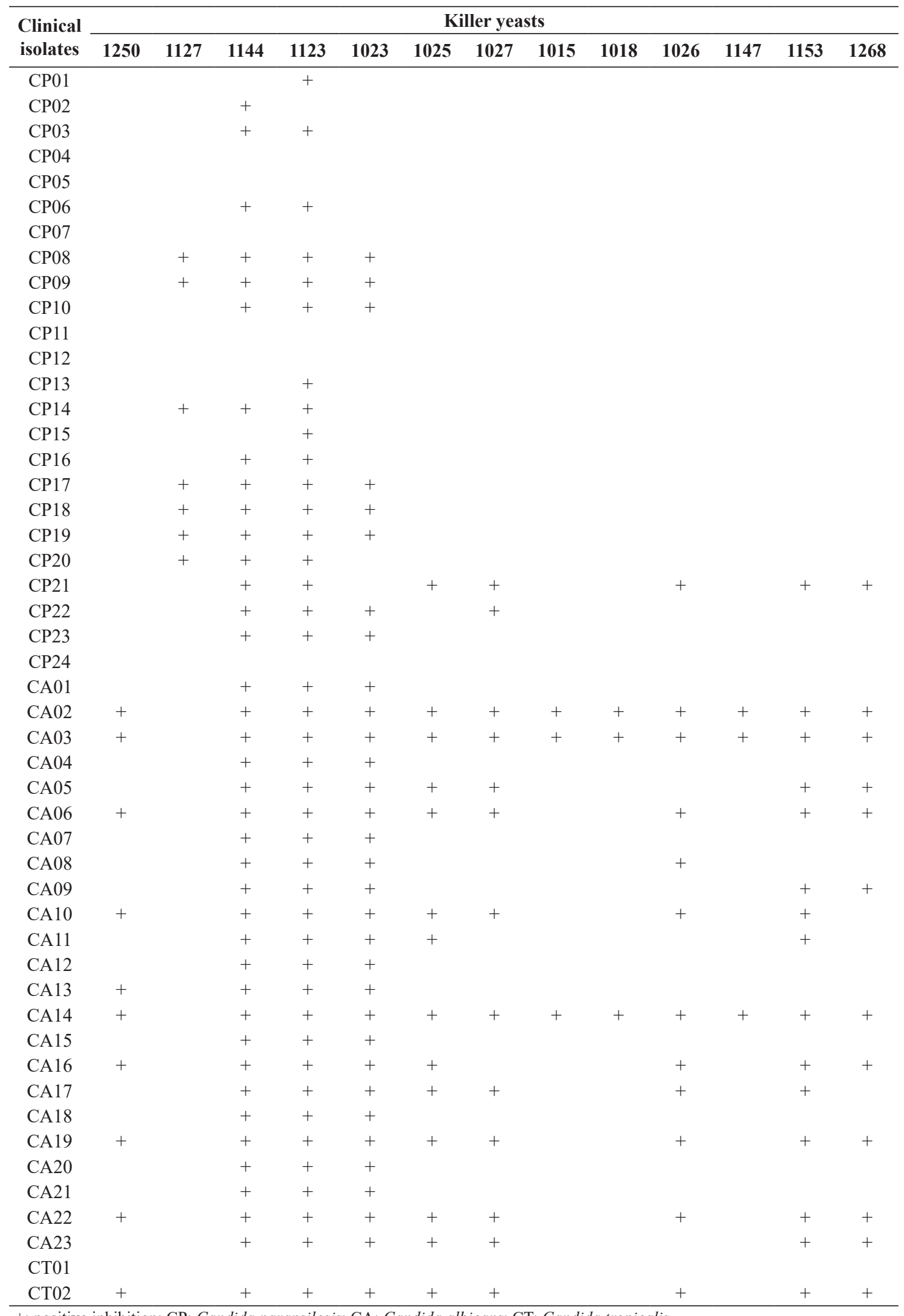

+: positive inhibition; CP: Candida parapsilosis; CA: Candida albicans; CT: Candida tropicalis. 
Table 3. Continued...

\begin{tabular}{|c|c|c|c|c|c|c|c|c|c|c|c|c|c|}
\hline \multirow{2}{*}{$\begin{array}{l}\text { Clinical } \\
\text { isolates }\end{array}$} & \multicolumn{13}{|c|}{ Killer yeasts } \\
\hline & 1250 & 1127 & 1144 & 1123 & 1023 & 1025 & 1027 & 1015 & 1018 & 1026 & 1147 & 1153 & 1268 \\
\hline \multicolumn{14}{|l|}{ СТ03 } \\
\hline \multicolumn{14}{|l|}{ СТ04 } \\
\hline \multicolumn{14}{|l|}{ СТ05 } \\
\hline СТ06 & + & & & & & + & + & + & + & + & + & + & + \\
\hline \multicolumn{14}{|l|}{ СТ07 } \\
\hline \multicolumn{14}{|l|}{ СТ08 } \\
\hline \multicolumn{14}{|l|}{ СТ09 } \\
\hline \multicolumn{14}{|l|}{ CT10 } \\
\hline \multicolumn{14}{|l|}{ CT11 } \\
\hline CT12 & + & & & & & + & + & + & + & + & + & + & + \\
\hline CT13 & & & & & & & & & & & & & \\
\hline
\end{tabular}

+: positive inhibition; CP: Candida parapsilosis; CA: Candida albicans; CT: Candida tropicalis.

not able to inhibit any Candida species group completely, they encourage the potential application of killer yeasts from the same species with a broader activity towards new antifungal therapies, both topical and systemic.

Killer activity is present in a wide diversity of yeasts but since the appropriate sensitive strain has to be used, many yeast species may have been misidentified as non-killer. It has been possible to differentiate between species of pathogenic yeasts using the killer system (Coutinho and Paula 1998; Scheid et al. 2010; Boekhout and Scorzetti 1997), and we suggest that it could be done for Candida species as well if a more taxonomically diverse panel of killer strains is employed. This would represent a rapid and low cost diagnostic tool. The value of such strategy would have a direct impact on therapy, due to the antifungal susceptibility differences among species (Treviño-Rangel et al., 2012; Fothergill et al., 2014).

On the other hand, antifungal resistance is a widely-reported issue that has become increasingly important, which has promoted the search for non-synthetic alternative, including plant extracts (Höfling et al., 2010). Currently, there is a remarkable need for better antifungals with high specificity and reduced toxicity. In our results, 3 yeasts were able to kill every C. albicans strain, suggesting that their killer toxin could potentially be used as a therapeutic alternative via the production of "antibiododies" as described and demonstrated by Polonelli et al. (2011). While these yeasts were not able to kill every Candida strain in our study, the extraordinary diversity of yeasts makes it highly probable for the existence of strains with a wider range of action or a specific effect against other species of pathogenic fungi. Uncommon yeasts from non-conventional sites, such as those reported by Moraes et al. (2005) may prove useful in accomplishing this.

Follow-up experiments to investigate the inhibitory nature of $M$. pulcherrima strains and towards the search for a killer panel able to differentiate among Candida species, as well as new killer yeasts capable of inhibiting other pathogenic fungi, are ensured.

\section{Acknowledgements}

We'd like to acknowledge the staff of the mycology laboratory at the Centro Regional de Control de Enfermedades Infecciosas for their technical support.

\section{References}

ARROYO-HELGUERA, O., PENAS ALEJANDRO DE, L. and IRENE, C., 2012. Occurrence of killer Candida glabrata clinical isolates. Brazilian Journal of Microbiology, vol. 43, no. 3, pp. 880-887. PMid:24031902. http://dx.doi.org/10.1590/ S1517-83822012000300005.

BECK-SAGUÉ, C.M. and JARVIS, W.R., 1993. The National Nosocomial Infection Surveillance System: secular trends in the epidemiology of nosocomial fungal infections in the United States, 1980-1990. The Journal of Infectious Diseases, vol. 167, no. 5, pp. 1247-1251. PMid:8486965. http://dx.doi.org/10.1093/ infdis/167.5.1247.

BEVAN, E.A. and MAKOWER, M. 1963. The inheritance of a killer character in yeast (Saccharomyces cerevisiae). In: Proceedings of the International Congress of Genetics XI, September 1963, The Hague, The Netherlands. Oxford: Pergamon Press, pp. 202-203.

BOEKHOUT, T. and SCORZETTI, G., 1997. Differential killer toxin sensitivity patterns of varieties of Cryptococcus neoformans. Journal of Medical and Veterinary Mycology, vol. 35, no. 2, pp. 147149. PMid:9147276. http://dx.doi.org/10.1080/02681219780001051.

BOURGEOIS, N., DEHANDSCHOEWERCKER, L., BERTOUT, S., BOUSQUET, P.J., RISPAIL, P. and LACHAUD, L., 2010. Antifungal susceptibility of 205 Candida spp. isolated primarily during invasive candidiasis and comparison of the Vitek 2 System with the CLSI broth microdilution and Etest methods. Journal of Clinical Microbiology, vol. 48, no. 1, pp. 154-161. PMid:19889902. http://dx.doi.org/10.1128/JCM.01096-09.

COUTINHO, S.D. and PAULA, C.R., 1998. Biotyping of Malassezia pachydermatis strains using the killer system. Revista Iberoamericana de Micologia, vol. 15, no. 2, pp. 85-87. PMid:17655416.

ESTEVE-ZARZOSO, B., BELLOCH, C., URUBURU, F. and QUEROL, A., 1999. Identification of yeasts by RFLP analysis of the 58S rRNA gene and two ribosomal internal transcribed 
spacers. International Journal of Systematic Bacteriology, vol. 49, no. 1, pp. 329-337. PMid:10028278. http://dx.doi. org/10.1099/00207713-49-1-329.

FERRER, C., COLOM, F., FRASES, S., MULE, T E., ABAD, J.L., ALIO, J.L., 2001. Detection and identification of fungal pathogens by PCR and by ITS2 and 5.8 ribosomal DNA typing in ocular infections. Journal of Clinical Microbiology, vol. 39, no. 8, pp. 2873-2879. PMid: 11474006. https://dx.doi.org/10.1128/ JCM.39.8.2873-2879.2001.

FOTHERGILL, A.W., SUTTON, D.A., MCCARTHY, D.I. and WIEDERHOLD, N.P., 2014. Impact of new antifungal breakpoints on antifungal resistance in Candida species. Journal of Clinical Microbiology, vol. 52, no. 3, pp. 994-997. PMid: 24403302. https://dx.doi.org/10.1128/JCM.03044-13.

FUJITA, S.I., SENDA, Y., NAKAGUCHI, S. and HASHIMOTO, T., 2001. Multiplex PCR using internal transcribed spacer 1 and 2 regions for rapid detection and identification of yeast strains. Journal of Clinical Microbiology, vol. 39, no. 10, pp. 3617-3622. PMid:11574582. http://dx.doi.org/10.1128/JCM.39.10.36173622.2001

GOLUBEV, W.I., 1998. Mycocins (killer toxins). The yeasts. In: C.P. KURTZMAN and J.W. FELL, eds. A taxonomic study. London: Academic Press, pp. 55-62.

HERNÁNDEZ-HERNÁNDEZ, F., CORDOVA-MARTÍNEZ, E., MANZANO-GAYOSSO, P., LOPEZ-ALVAREZ, R., BAZANMORA, E. and LÓPEZ-MARTINEZ, R., 2003. Frecuencia de micosis en pacientes inmunosuprimidos de un hospital regional de la Ciudad de México. Salud Pública de México, vol. 45, no. 6, pp. 455-460. PMid:14974289. http://dx.doi.org/10.1590/S003636342003000600005

HÖFLING, J.F., ANIBAL, P.C., OBANDO-PEREDA, G.A., PEIXOTO, I.A.T., FURLETTI, V.F., FOGLIO, M.A. and GONÇALVES, R.B., 2010. Antimicrobial potential of some plant extracts against Candida species. Brazilian Journal of Biology $=$ Revista Brasileira de Biologia, vol. 70, no. 4, pp. 1065-1068. http://dx.doi.org/10.1590/S1519-69842010000500022.

JIN, J., LEE, Y.K. and WICKES, B.L., 2004. Simple chemical extraction method for DNA isolation from Aspergillus fumigatus and other Aspergillus species. Journal of Clinical Microbiology, vol. 42, no. 9, pp. 4293-4296. PMid:15365025. http://dx.doi. org/10.1128/JCM.42.9.4293-4296.2004.

KURTZMAN, C.P. and ROBNETT, C.J., 1998. Identification and phylogeny of ascomycetous yeasts from analysis of nuclear large subunit (26S) ribosomal DNA partial sequences. Antonie van Leeuwenhoek, vol. 73, no., 4, pp. 331-371. PMid:9850420. http://dx.doi.org/10.1023/A:1001761008817.

LANDLINGER, C., BASKOVA, L., PREUNER, S., WILLINGER, B., BUCHTA, V. and LION, T., 2009. Identification of fungal species by fragment length analysis of the internally transcribed spacer 2 region. European Society of Clinical Microbiology, vol. 28, no. 6, pp. 613-622. PMid: 19104852. https://dx.doi. org/10.1007/s10096-008-0683-3.

MAGLIANI, W., CONTI, S., SALATI, A., VACCARI, S., RAVANETTI, L., MAFFEI, D.L. and POLONELLI, L., 2004. Therapeutic potential of yeast killer toxin-like antibiodies and mimotopes. FEMS Yeast Research, vol. 5, no. 1, pp. 11-18. PMid:15381118. http://dx.doi.org/10.1016/j.femsyr.2004.06.010.

MESSER, S.A., MOET, G.J., KIRBY, J.T. and JONES, R.N., 2009. Activity of contemporary antifungal agents, including the novel echinocandin anidulafungin, tested against Candida spp., Cryptococcus spp. and Aspergillus spp.: Report from the SENTRY Antimicrobial Surveillance Program (2006-2007). Journal of Clinical Microbiology, vol. 47, no. 6, pp. 1942-1946. PMid:19386851. http://dx.doi.org/10.1128/JCM.02434-08.

MORAES, M.E., ROSA, C.A. and SENE, F.M., 2005. Preliminary notes on yeasts associated with necrotic cactus stems from different localities in Brazil. Brazilian Journal of Biology $=$ Revista Brasileira de Biologia, vol. 65, no. 2, pp. 299-304. http:// dx.doi.org/10.1590/S1519-69842005000200014.

NUCCI, M., SPECTOR, N., BUENO, A.P., SOLZA, C., PERECMANIS, T., BACHA, P.C. and PULCHERI, W., 1997. Risk factors and attributable mortality associated with superinfections in neutropenic patients with cancer. Clinical Infectious Diseases, vol. 24 , no. 4, pp. 575-579. PMid:9145730.

POLONELLI, L., MAGLIANI, W., CIOCIOLA, T., GIOVATI, L. and CONTI, S., 2011. From Pichia anomala killer toxin through killer antibodies to killer peptides for a comprehensive anti-infective strategy. Antonie van Leeuwenhoek, vol. 99, no. 1, pp. 35-41. PMid:20714805. http://dx.doi.org/10.1007/s10482-010-9496-3.

POLONELLI, L., MAGLIANI, W., CONTI, S., BRACCI, L., LOZZI, L., NERI, P., ADRIANI, D., DE BERNARDIS, F. and CASSONE, A., 2003. Therapeutic activity of an engineered synthetic killer antiidiotypic antibody fragment against experimental mucosal and systemic Candidiasis. Infection and Immunity, vol. 71, no. 11, pp. 6205-6212. PMid:14573638. http://dx.doi. org/10.1128/IAI.71.11.6205-6212.2003.

ROBLEDO-LEAL, E., VILLARREAL-TREVIÑO, L. and GONZÁLEZ, G.M., 2012. Occurrence of killer yeasts in isolates of clinical origin. Tropical Biomedicine, vol. 29, no. 2, pp. $297-$ 300. PMid:22735852.

SAMBROOK, J. and RUSSELL, D., 2001. Molecular cloning: a laboratory manual. New York: Cold Spring Harbor Laboratory.

SCHEID, L.A., MARIO, D.A.N., HEINS-VACCARI, E.M., SANTURIO, J.M. and ALVES, S.H., 2010. Differentiation of Candida dubliniensis from Candida albicans with the use of killer toxins. Revista do Instituto de Medicina Tropical de Sao Paulo, vol. 52, no. 3, pp. 161-162. PMid:20602027. http://dx.doi. org/10.1590/S0036-46652010000300009.

SOUZA CABRAL, A., CARVALHO, P.M., PINOTTI, T., HAGLER, A.N., MENDONÇA-HAGLER, L.C. and MACRAE, A., 2009. Killer yeasts inhibit the growth of the phytopathogen Moniliophthora perniciosa, the causal agent of Witches' Broom disease. Brazilian Journal of Microbiology, vol. 40, no. 1, pp. 108-110. PMid:24031327. http://dx.doi.org/10.1590/S151783822009000100018

TREVIÑO-RANGEL, R.D.J., GARZA-GONZÁLEZ, E. and GONZÁLEZ, J.G., BOCANEGRA-GARCÍA, V., LLACA, J.M., GONZÁLEZ, G.M., 2012. Molecular characterization and antifungal susceptibility of the Candida parapsilosis species complex of clinical isolates from Monterrey, Mexico. Medical Mycology, vol. 50, no. 7, pp. 781-784. PMid: 22493945. https:// dx.doi.org/10.3109/13693786.2012.675526.

TROST, A., GRAF, B., EUCKER, J., SEZER, O., POSSINGER, K., GÖBEL, U.B. and ADAM, T., 2004. Identification of clinically relevant yeasts by PCR/RFLP. Journal of Microbiological Methods, vol. 56, no. 2, pp. 201-211. PMid:14744449. http:// dx.doi.org/10.1016/j.mimet.2003.10.007.

WHITE, P.L., SHETTY, A. and BARNES, R.A., 2003. Detection of seven Candida species using the light-cycler system. Journal 
of Medical Microbiology, vol. 52, no. 3, pp. 229-238. PMid: 12621088. https://dx.doi.org/10.1099/jmm.0.05049-0.

WISPLINGHOFF, H., BISCHOFF, T., TALLENT, S.M., SEIFERT, H., WENZEL, R.P. and EDMOND, M.B., 2004.
Nosocomial bloodstream infections in US hospitals: analysis of 24,179 cases from a prospective nationwide surveillance study. Nephrology, Dialysis, Transplantation, vol. 39, no. 3, pp. 309-317. PMid:15306996. https://dx.doi.org/10.1086/421946. 